\title{
IZOBRAŽEVANJE V UČEČI SE ORGANIZACIJI
}

Mag. Henrik

Dovžan

\section{Kakšni načini učenja spodbujajo delovno učinkovitost?}

\section{POVZETEK}

$V$ sestavku obravnavamo dejavnike, $k i$ pomembno vplivajo na povečanje delovne učinkovitosti človeških virov organizacije: intelektualni kapital, samoizobraževanje, akcijsko učenje, uporabno znanje podjetja in mreže za razvoj znanja. Intelektualni kapital, to je kombinacija izobrazbe, znanja in izkušenj, je najpomembnejše proizvodno sredstvo. Samoizobraževanje je nova pot do znanja, ko odgovornost za pridobivanje znanja sprejemajo vsi zaposteni in se tudi dejansko izobražujejo. Akcijsko učenje obsega domišljïjo, ustvarjalnost, upoštevanje dejstev in vrednot, odgovornost za odločitve, razmišljanja o dolgoročnih učinkih sprejetih odločitev, alternativo, demokratičnost. Uporabno znanje podjetja je vtkano $v$ vse pore podjetja. Mogoče ga je razdeliti v tri skupine: znanje posameznika, znanje skupin in utelešeno oziroma izrecno znanje. Podjetniške mreže pa so sredstvo za doseganje konkurenčne prednosti, kjer partnerji sodelujejo tako, da spoznajo medsebojne potrebe, delijo znanje in izkušnje, si skupaj prizadevajo za povečanje produktivnosti $v$ korist vseh in predvidevajo spremembe, ki lahko vplivajo na njihovo partnerstvo v prihodnje.

Ključne besede: učeča se družba, znanje, intelektualni kapital, učenje, razvoj
Informacijska družba, poindustrijska đružba ali družba znanja prinaša nove vrednote. Človeka cenimo po njegovih sposobnostih, ustvarjalnosti, znanju, izkušnjah in kompetencah. Pri delu in v življenju čedalje bolj poudarjamo intelektualne in emocionalne sposobnosti ljudi. Izzivi iz današnjega globalnega okolja narekujejo nenehno spreminjanje organizacij, ki se vsakodnevno srečujejo s pritiski notranjih in zunanjih okolij. Zaposleni so za organizacijo potencial, ki ustvarja konkurenčne prednosti. Zato jih je potrebno nenehno izobraževati, usposabljati, izpopolnjevati.

$\mathrm{V}$ pričujočem prispevku razmišljamo o dejavnikih, ki pomembno vplivajo na povečanje delovne učinkovitosti v organizaciji: intelektualni kapital, samoizobraževanje, akcijsko učenje, uporabno znanje in mreže za razvoj znanja.

Upravljanje znanja je proces, ki se nikoli ne konča. V upravnih strukturah sodobnih podjetij zahodnega sveta najdemo direktorje za informatiko ('chief information officers' CIO), direktorje za "znanje" ('chief knowledge officers' - CKO) in direktorje za učenje ('chief learning officers' - CLO). Njihov prispevek $\mathrm{k}$ učinkovitosti podjetja se kaže zlasti na naslednjih področjih:

- sistematičnem reševanju problemov;

- sistematičnem iskanju, pridobivanju in preizkušanju novih znanj v praksi; 
- učenju zaposlenih iz lastnih preteklih uspehov in napak;

- učenju iz tujih izkušenj (benchmarking, zgledovanje) in

- hitrem ter učinkovitem prenosu znanja znotraj organizacije.

\section{INTELEKTUALNI KAPITAL -} KOMBINACIJA IZOBRAZBE, ZNANJA IN IZKUŠENJ ZAPOSLENIH V PODJETJU

\section{Pripadnost po- djetju danes vse bolj povezujemo z možnostjo oseb- nega razvoja.}

Podjetja danes trdega dela in zvestobe ne nagrajujejo več samodejno $\mathrm{z}$ varnim delovnim mestom do upokojitve. Zaradi nujnosti nenehnega prenavljanja se med presežki pogosto znajdejo tudi sposobni in dobri delavci.
Pripadnost podjetju zaposleni povezujejo z možnostjo za osebni razvoj izboljšanje ali uresničevanje sposobnosti in možnosti posameznika na temelju učenja in izkušenj, ki si jih ta pridobi v procesu izobraževanja. Posamezniki ostajajo v podjetju tako dolgo, dokler čutijo, da se lahko razvijajo. Pripadnost podjetja odstopa mesto

Ameriški menedžerski mislec Peter Drucker meni, da intelektualni kapital kombinacija izobrazbe, znanja in izkušenj - kot najpomembnejše proizvodno sredstvo pripada $v$ podjetju visoko usposobljenim delavcem in ne more preiti $v$ last drugih. Namesto starega (marksističnega) razrednega nasprotja danes stopa $v$ ospredje nov konflikt med manjšino tistih, ki imajo znanje, ki je redko in skopo odmerjeno (razvijalci programske opreme, sistemski analitiki, inovatorji), in običajnimi delojemalci s sposobnostmi, ki jih je v izobilju. pripadnosti stroke. Ko sposobni delavec $\mathrm{v}$ podjetju ugotovi, da so njegove intelektualne sposobnosti slabo izkoriščene, prične sam skrbeti za svoj razvoj in posredno za svojo vrednost na trgu dela.

Vešči podjetniki zato radi zagotavljajo nadarjenim posameznikom optimalne možnosti za delo, izobraževanje in razvoj, kajti to je edini način, da jih zadržijo $v$ organizaciji. Podjetniku vlaganje $\mathrm{v}$ izobraževanje prinaša želene učinke takrat, ko poleg znanja, potrebnega za današnjo uspešnost podjetja, zagotavlja tudi znanje, $\mathrm{ki}$ bo podjetju omogočilo dolgoročno uspešno poslovanje.

Da bi zaposleni $v$ podjetju dosegel stopnjo zrelosti, odličnosti, je potrebno nenehno učenje in izpopolnjevanje po naslednjih stopnjah:

- UVAJANJE: sestavljeno je iz spoznavanja novega dela s tehnične in družbene plati. Tehnični del je sestavljen iz opisa del, ki jih mora delavec opraviti, družbeni pa iz pravil vedenja, ki veljajo v tem okolju.

- VKLJUČITEV: pomeni pridobitev zaupanja pri sodelavcih tako, da smo sprejeti $v$ mikrookolje in lahko uspešno sodelujemo $v$ njem. Ta del je po navadi prepuščen vsakemu posamezniku, čeprav je večkrat izvor navzkrižij.

- VPLIVNOST: posameznik mora pridobiti vpliv na sodelavce.

- OSEBNI RAZVOJ: pomeni pridobivanje znanj, spretnosti in veščin z najrazličnejših področij, ki je nujno povezano s pridobivanjem znanja in vseživljenjskim izobraževanjem. Med najpomembnejša področja osebnega razvoja sodijo:

- strokovno znanje: nujen, neogiben, prvi pogoj;

- komunikativnost: posameznik izraža marljivost, navdušenost, vztrajnost, razumevanje, etiko, dinamičnost, samozavest;

- pogajalske sposobnosti: kot pokazatelj 


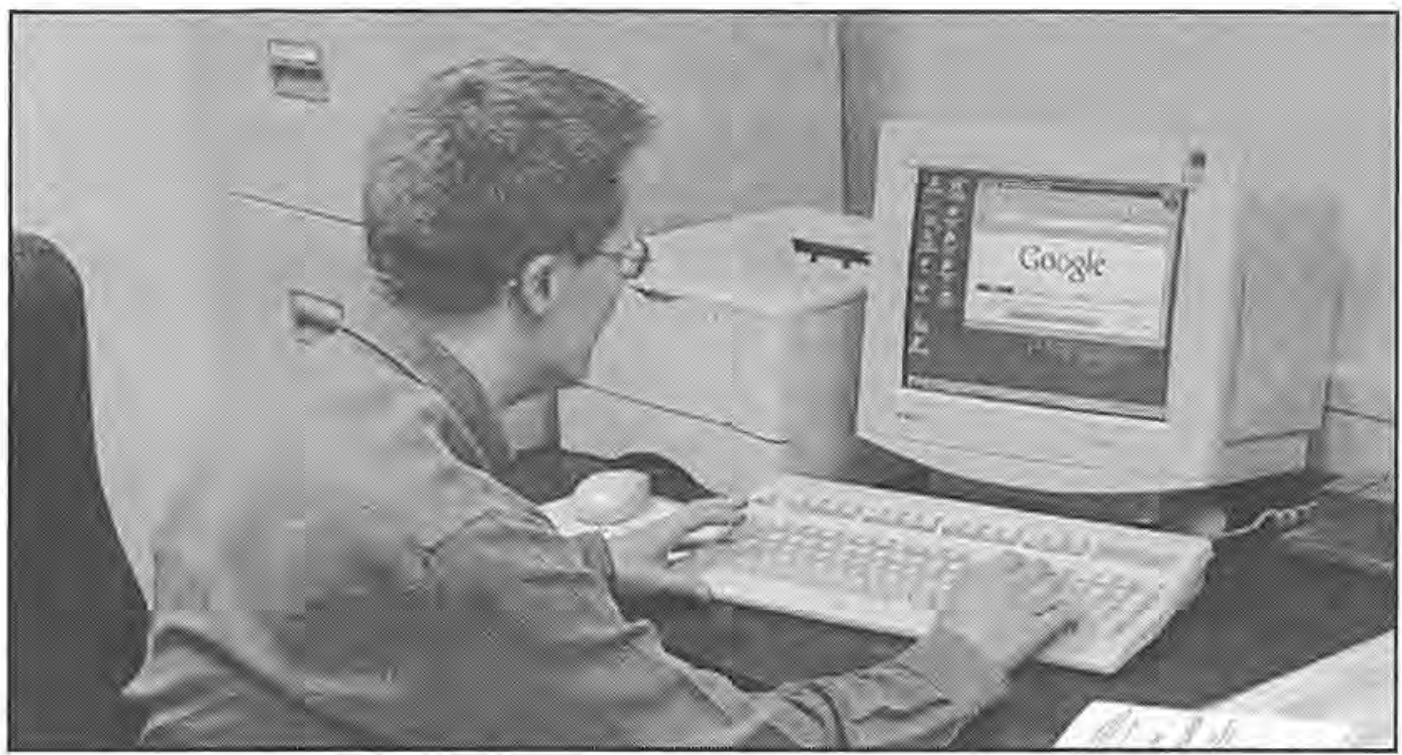

kakovosti sodelavca se navadno poudarjajo pri delovnih mestih $\mathrm{v}$ stiku z ljudmi (animacija, prodaja, nabava itd.) in predstavljajo sposobnost ljudi, da prodajo stvari, znajo prepričevati, pojasnjevati, so dovolj agresivni, vztrajni, verbalno okretni, dinamični itd.;

- organizacijske sposobnosti: predstavljajo pomemben temelj za opravljanje vodstvenih in izvršilnih delovnih nalog, vendar te sposobnosti pridejo prav na vsakem delovnem mestu: človek, ki zna organizirati delo, navadno to delo tudi zlahka in uspešno opravi;

- samoiniciativnost: samoiniciativen delavec je predvsem samostojen pri iskanju izboljšav za delovne naloge, ki jih mora opraviti, razume, $v$ čem je korist organizacije in temu primerno oblikuje svoje delovno mesto;

- pripravljenost za izobraževanje: pomeni, da se je delavec pripravljen izobraževati, da bi čim bolje opravljal svoje delo;

- samostojnost: za samostojne navadno štejemo delavce, ki so sposobni opravljati delo samostojno, brez posebnih oblik uvajanja, brez posebnih napotkov za izvajanje dela in tudi brez posebnega nadzora glede discipline;

- učinkovitost: v praksi opažamo, da je storilnost nekega delavca mnogo višja od drugega, da nekdo opravi neko delo bolje in hitreje kot drugi, da hitro dojame nove elemente okolja in jih vključi v delo;

- kreativnost: ocenjujemo jo pri delavcih po vnašanju novosti, ki prispevajo $\mathrm{k}$ dohodku podjetja; posebej je pomembna $v$ povezavi s timskim delom;

- dinamičnost: živahen pristop do opravljanja dela, zanimanje za delo in entuziazem.

\section{SAMOIZOBRAŽEVANJE - NOVA POT DO ZNANJA IN ZAPOSLIIVOSTI}

Danes ne govorimo več o zahtevah delovnega mesta, temveč o kompetencah, ki obsegajo znanje, veščine, izkušnje, ambicije, pričakovanja, stališča in norme. Vse to prispeva, da se človek pri delu samoaktualizira. Pri tem je pomembno, da posameznik sam skrbi za svojo kariero in povečanje svoje kompetentnosti.

$\mathrm{Na}$ ravni kompetentnosti se posameznik 
odloča, ali bo povečeval svoje znanje, spretnosti, sposobnosti in veščine široko - si poskušal pridobiti večji krog znanja in sposobnosti - ali pa se bo specializiral in poglobil znanje $z$ enega področja. Prav tako se mora odločiti, ali bo "zvesto služil" določeni organizaciji, ji bo torej lojalen, sprejel vse njene vrednote, kulturne vzorce in

\section{Znanje v organiza- ciji postane vir sele, ko ga lahko vkljucimo v pro- cese poslovanja.}

$\mathrm{v}$ njej iskal svojo dokončno realizacijo - tako se legitimira nova pot do znanja - samoizobraževanje. Tudi družba kot celota postane družba znanja šele takrat, ko odgovornost za pridobivanje znanja sprejemajo vsi in se tudi dejansko izobražujejo.

Vseživljenjsko učenje za vse obsega trajno učno aktivnost za izboljševanje znanja, spretnosti in veščin, ki so potrebne za zaposljivost. Vseživljenjsko učenje je dvodimenzionalno. Časovna dimenzija obravnava učenje $v$ začetnem izobraževanju (otrok, mladine) in $v$ nadaljevalnem izobraževanju (odrasle osebe). Vsebinska dimenzija pa enakovredno obravnava formalno, neformal-

Tudi Evropska unija se razvija $v$ smeri tekmovalne, dinamične, na znanju temelječe ekonomije, saj je to pogoj zagotovitve trajne ekonomske rasti posameznih držav članic. Le takšen pristop lahko zagotovi prebivalstvu držav članic Unije večjo zaposljivost in socialno varnost. Cilj bo lahko uresničen le $\mathrm{z}$ udejanjanjem vseživljenjskega učenja za vse. To je praktično tudi edini izhod za korekcijo proporcev Huttonovega principa 30/30/40, ki ugotavlja, da je delovno sposobna populacija razdeljena $\mathrm{v}$ tri skupine: 30 odstotkov ljudi je brezposelnih, enak odstotek jih ima nezanesljivo, začasno službo, 40 odstotkov pa ima stalno zaposlitev oziroma so samozaposleni. no in priložnostno izobraževanje in učenje. To poudarja tudi Memorandum Evropske unije o vseživljenjskem učenju (Lizbona, marec 2000).

Za podjetje postane znanje posameznikov resničen vir šele takrat, ko ga je mogoče vključiti v procese poslovanja. Zaradi tega se $\mathrm{v}$ strokovni literaturi srečujemo $\mathrm{z}$ naslednjo razvrstitvijo znanja, ki temelji na njegovi vključitvi v poslovne procese:

- konceptualno znanje (know-what), ki predstavlja temeljno znanje na določenem področju in ga pridobimo $\mathrm{z}$ dolgotrajnim šolanjem in usposabljanjem;

- aplikativno znanje (know-how), ki omogoča prevesti "knjižno znanje" v učinkovito izvedbo;

- sistemsko znanje (know-why), ki pogojuje poglobljeno razumevanje spleta vzročnih odnosov na določenem področju, predvidevanje interakcije različnih vplivnih dejavnikov in možne posledice;

- motivirana kreativnost (care-why), ki obsega poleg že omenjenih oblik znanja še motivacijo, vztrajnost in prilagodljivost. Njen pomen lahko opazimo, kadar enako usposobljeni zaposleni, ki razpolagajo $\mathrm{z}$ enakimi materialnimi in finančnimi viri, dosegajo zelo različne rezultate.

Formalno izobraževanje daje predvsem temeljno konceptualno znanje, medtem ko si ostala znanja pridobimo le $\mathrm{z}$ delom $\mathrm{v}$ konkretni delovni in življenjski situaciji, z akcijskim, izkustvenim učenjem.

\section{REŠEVANJE PROBLEMOV Z AKCIJSKIM UČENJEM}

Tradicionalno gledano je učenje ena stvar, reševanje resničnih problemov pá druga. Seveda rešujemo probleme tudi pri učenju, vendar so to največkrat posebej izbrani, 
simulirani problemi, ki jih je treba rešiti, da bi se s tem nekaj naučili.

Akcijsko učenje spada med modele učenja, ki jih v teoriji označujemo s skupnim imenom izkustveno učenje. Za akcijsko učenje je značilno ravno to, da postavlja $\mathrm{v}$ ospredje resnični problem in ponuja metodo, kako spoznati, razčleniti in šele nato poiskati rešitev.

Toda $\mathrm{z}$ najdeno rešitvijo naloge še nismo končali, problem moramo rešiti tudi v praksi. Ker so problemi večplastni, odprti, vključujemo skupino ljudi, ki se med reševanjem problema načrtno in sistematično uči.

Akcijsko učenje vključuje domišljijo, ustvarjalnost, upoštevanje dejstev in vrednot, odgovornost za odločitve, razmišljanja o dolgoročnih učinkih sprejetih odločitev, alternativo, demokratičnost.

Življenje se nenehno spreminja in zahteva od nas, da se prilagajamo spremembam. $\mathrm{Ni}$ uvajanja sprememb brez učenja. To potrjuje tudi primer, ki se je pripetil Tomu Watsonu, ustanovitelju IBM-a. Eden njegovih podrejenih je naredil ogromno napako, ki je podjetje stala 10 milijonov dolarjev. Ko je bil zaposleni poklican v Watsonovo pisarno, je svojemu šefu dejal: "Predvidevam, da pričakujete, da bom dal odpoved". Watson je odgovoril: "Ali se šališs Za tvoje izobraževanje smo pravkar zapravili 10

\footnotetext{
Akcijsko učenje zahteva:

- reševanje problemov z združevanjem znanj;

- celostno razmišljanje;

- intuitivno mišljenje;

- skupinsko sodelovanje z upoštevanjem solidarnosti, alternativnih predlogov, etičnih vidikov in

- spoštovanje individualne in družbene identitete.
}

milijonov dolarjev." Učenje ni luksuz, je način, kako podjetje odkriva svojo prihodnost.

V današnjem turbulentnem okolju je sposobnost preživetja podjetja odvisna predvsem od dveh dejavnikov:

- kakovosti znanja in sposobnosti zaposlenih v podjetju glede na konkurenco ter

- uspešnosti podjetja, da $v$ čim večji meri izkoristi potencial, ki se skriva v zaposlenih.

Znanje in neopredmeteni (nematerialni) viri so temeljno premoženje, ki ohranja in spodbuja podjetniško konkurenčnost. Podjetje je sistem, ki raste predvsem zaradi svojega neopredmetenega preUčenje je način, kako podjetje odkriva svojo prihodnost. moženja in znanja, ne pa materialnega premoženja. Proizvodnja in reprodukcija znanja je osnova fizičnih procesov in omogoča inoviranje, ustvarjanje novih povezav s kupci, $\mathrm{z}$ dobavitelji in s finančnimi institucijami. Znanje daje vrednost materialni proizvodnji. Proizvodnja znanja in upravljanje procesov proizvodnje, akumulacija in razširjenost obstoječega znanja postajajo ključni dejavnik donosnosti ali celo obstoja podjetja.

\section{UPORABNO ZNANJE PODJETJA}

$S$ podjetniškega vidika vse znanje ni enako zanimivo in koristno. Pomemben je le tisti del znanja, ki ga strokovna literatura pogosto opredeljuje kot uporabno znanje podjetja. Tako v podjetjih Iočujemo tista znanja, ki jih lahko koristimo, od znanj, ki jih podjetje neposredno ne uporabi. Cilj uporabnega znanja podjetja je doseganje uspešnega poslovanja podjetja.

Uporabno znanje je vtkano $v$ vse pore podjetja. Mogoče ga je razdeliti v tri skupine: 


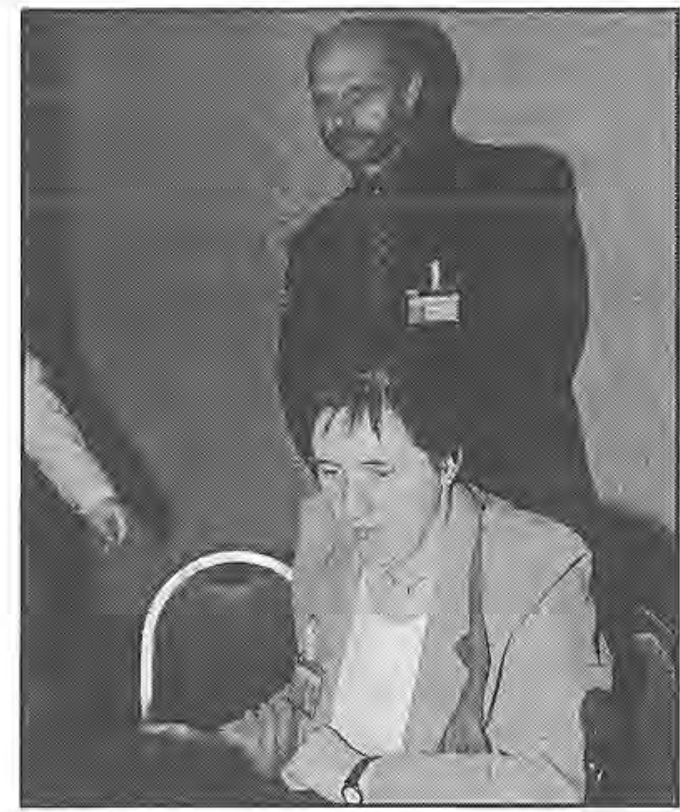

- znanje posameznika (tacit knowledge), ki ga ima ta v svoji glavi (finančno, inženirsko znanje, znanje o človeških virih, upravljalsko, podjetniško ...);

- znanje skupin (shared knowledge) in

- utelešeno oziroma izrecno znanje (embodied knowledge), ki je formalizirano, eksplicitno izraženo in ga je možno distribuirati (blagovna znamka, kupci, dobavitelji) ...

Znanje je niz formalnih in sistematičnih podatkov ter kodificiranih postopkov, ki pomembno prispevajo $\mathrm{k}$ ustvarjanju poslovnih učinkov. Poslovne učinke običajno merimo s kriteriji za presojo znanja: povečana učinkovitost, nižji stroški, višji donos. Pojavljajo pa se tudi drugačni, sofisticirani kriteriji presojanja poslovnih učinkov: hitra odzivnost podjetja na spremembe $\mathrm{v}$ okolju, kar je navadno posledica izvirnejših pristopov k obvladovanju ustvarjanja novega znanja. Pri tem ne gre zgolj za preprosto obdelavo objektivnih informacij, temveč za zajetje molčečega znanja, prebliskov in intuicij posameznih zaposlenih ter spremembo tega $\mathrm{v}$
V kreativnem podjetju nastane spirala znanja, dinamična interakcija med raznimi vrstami znanja: molčeče znanje se pretvarja $v$ molčeče (opazovanje) in eksplicitno (artikukacija $\mathrm{v}$ prenosljivo obliko); eksplicitno se spreminja $\mathrm{v}$ molčeče (internalizacija pri zaposlenih) in $\mathrm{v}$ eksplicitno (posameznik sintetizira delce objektivnih znanj v novo celoto). Kritični točki v prenosu znanj sta artikulacija in internalizacija, saj terjata osebno zavzetost. Zaposleni si izmenjujejo znanje $\mathrm{z}$ dokumenti, srečanji, telefonskimi pogovori, računalniškim omrežjem itd. Obstoječe informacije tako preko razvrščanja, dodajanja, kombiniranja in kategoriziranja vodijo do novega znanja.

uporabno vrednost za celotno podjetje.

Novo znanje zmerom izvira iz posameznika. Naloga podjetja je to znanje narediti razpoložljivo zaposlenemu osebju. V primeru "trdega", eksplicitnega, sistematičnega in formalnega znanja to ni težavno. Drugače pa je z molčečim znanjem, ki se le stežka formalizira in posreduje. Gre za znanje, tesno povezano s posameznikovim opravljanjem dejavnosti - bogastvo spretnosti in znanj, ki se nabere v letih izkušenj. Vtkano je v osebnost in se ga velikokrat niti ne zavedamo.

\section{NOVE TEHNOLOGIJE IN USTVARJANJE NOVEGA ZNANJA}

Internalizacija je proces pretvorbe zunanjega (eksplicitnega) znanja $\mathrm{v}$ notranje (tacitno) znanje. Tesno je povezana $\mathrm{z}$ izkustvenim učenjem. Pri internalizaciji je pomembno, da se znanje shrani $v$ dokumente, priročnike, scenarije itd. $S$ tem obogatimo znanje posameznika, posredno pa tudi podjetja in tako ustvarjamo novo znanje $\mathrm{v}$ njem.

Zmanjševanje stroškov komunikacije in prenosa ter obdelave informacij povečuje 
kakovost in hitrost odločanja, kar vodi $\mathrm{k}$ decentralizaciji upravljalnih struktur. Nove komunikacijske in informacijske tehnologije, kot so:

- groupware (elektronska pošta, računalniške konference, računalniško oblikovanje, računalniški inženiring itd.),

- internet,

- intranet in

- ekstranet,

imajo osrednjo vlogo pri delitvi dela in ustvarjanju novega znanja.

Razvoj informatike in elektronike zahtevata ustvarjalnega in "unikatnega" človeka, ki mu informacije in faktografsko znanje sproti omogočajo elektronski mediji, daleč presegajoči spomin in druge njegove psihofizične sposobnosti.

\section{MREŽE - PROŽNE ORGANIZACIJE ZA RAZVOI ZNANJA}

Pojem mreža se v poslovni literaturi pogosto pojavlja. V strokovni literaturi s področja organizacije navadno najdemo obrazložitev, da je povod vstopanja podjetij $\mathrm{v}$ določene podjetniške, dinamične, svetovalne in druge mreže iskanje in izkoriščanje konkurenčnih prednosti, ki zadevajo vrednotenje znanja, tako organizacijskega kot posameznikovega. Zato postajajo podjetniške mreže sredstvo za doseganje konkurenčne prednosti, saj partnerji sodelujejo tako, da spoznajo medsebojne potrebe, delijo znanje in izkušnje ter si skupaj prizadevajo za povečanje produktivnosti v korist vseh in skupaj predvidevajo spremembe, ki lahko vplivajo na njihovo partnerstvo v prihodnje.

Razen splošnih zunanjih vplivov, kot so pojav vedno intenzivnejše mednarodne konkurence, tehnološki in splošni napredek ter globalizacija, izvirajo motivi mrežnih povezav iz naslednjih vzrokov:

- reševanja razvojnih problemov (odprava primanjkljaja v resursih) in

- izkoriščanja priložnosti (optimalno in dopolnjujoče sinergijsko izkoriščanje razpoložljivih resursov članov mreže).

$\mathrm{V}$ izobraževalnem menedžmentu pa predstavlja mreža splet povezav in komunikacijskih tokov, ki omogočajo uspešnost in učinkovitost $v$ procesu ustvarjanja znanja. Omrežje tako omogoča hitro širjenje znanja različnih področij in povečuje uporabno znanje udeležencev.

Podjetniška mreža omogoča doseči udeležencem to, česar sami ne zmorejo. Podjetniki se danes ne morejo več zanesti zgolj na svoje notranje moči, povezati se morajo med seboj za pridobitev manjkajočih komplementarnih resursov.

\section{UČEČA SE DRUŽBA}

Izobraževanje postaja temeljna dejavnost tudi $\mathrm{z}$ vidika družbe in ne le posameznika. Razvoj družbe prinaša prehajanje aktivnega prebivalstva iz enega ekonomskega sektorja $\mathrm{v}$ drugi sektor, iz sekundarnega (industrije in rudarstva) v terciarni (storitvene dejavnosti: turizem, gostinstvo, obrt, kultura, šolstvo, zdravstvo, banke itd.). Zaposlenost v industriji se je v zadnjih desetletjih znižala s 60 na 25 odstotkov, Zaposlenost v terciarnem sektorju ekonomije pa se je povzpela z 20 odstotkov v industrijski družbi na 60 odstotkov v poindustrijski družbi - učeči se družbi.

Izredno hitro se razvija tako imenovani kvartarni sektor oziroma zaposlovanje $v$ znanosti in tehnologiji, inovatorstvu in razvoju. V informacijski, poindustrijski družbi zajema kvartarni sektor dobro četrtino aktivnega prebivalstva. Razvoj sodobnih informacijskih in komunikacijskih tehnologij 
$\mathrm{V}$ učeči se družbi sta znanje in inovacija pomembnejša dejavnika konkurenčnosti kot kapital. Razvoj večstrankarske demokracije in demokracije na delovnem mestu spremlja upravljalska demokracija $v$ poslovnem sistemu in mnogo lobijev $\mathrm{v}$ družbeni demokraciji. Podjetja se usmerjajo h globalnim spremembam. Temeljni cilj je oblikovanje vizije podjetja in ustvarjanje kulture sprememb med zaposlenimi. Vodstva spodbujajo poslovna eksperimentiranja in podjetniško inovativnost med zaposlenimi.

pospešujejo štirje dejavniki: globalizacija trgov, razširjenost informacijske tehnologije in računalniških mrež, odstranitev tradicionalne upravljalske hierarhije in ustvarjanje nove informacijske ekonomije.

Zaposlenost $v$ industriji se je $v$ zadnjih desetletjih znižala za 35 odstotkov.
Potrošniki in poslovni partnerji postajajo del dolgoročnih poslovnih mrež, ki gojijo kulturo soodvisnosti in sodelovanja. Neprestane spremembe na vseh področjih poslovanja so temeljni vzvodi razvoja podjetja, ki svojo organizacijo gradi na mehkih elementih poslovne kulture in družbene odgovornosti do poslovnega okolja.

\section{SKLEP}

$\mathrm{Za}$ vse zaposlene in podjetja je učenje bistvenega pomena. Izobraževanje pa ni nič drugega kot načrtno učenje, zato mora biti povezano $s$ ključnimi dejavniki razvoja in rasti podjetja.

Negotovo okolje podjetja zahteva od vodstev podjetij nove izobraževalne vsebine, ki upoštevajo različnosti življenjskih slogov, vrednostne sisteme posameznikov, njihove cilje in potrebe ter želje po uveljavitvi in priznanju. Sodobna podjetja uresničujejo želje in zahteve zaposlenih na različne načine. Omenimo zgolj nekatere:

- vključevanje ciljev podjetja $v$ individualne delovne cilje;

- možnosti uveljavljanja osebne iniciative;

- sodelovanje zaposlenih pri sprejemanju pomembnejših odločitev;

- izpopolnjevanje sodelavcev zunaj organizacije;

- razvejanost skupinskega dela;

- povezanost organizacije z okoljem;

- spremljanje delovne učinkovitosti sodelavcev in posredovanje vinitvenih sporočil;

- vključevanje $v$ izobraževalne proceșe itd.

S tem podjetja oblikujejo novo filozofijo učenja, ki poudarja celovitost podjetja, osebnosti in razvoja. V življenjskih položajih zaposlenih učenje tako postaja celovito, ne zgolj spoznavni proces temveč splet razmišljanja, čustvovanja in praktične dejavnosti na delovnem mestu.

\section{LITERATURA}

Hirotaka T., Nonaka, I. (1995). The KnowledgeCreating Company. Oxford University Press.

Laszlo, E. (1998). Das dritte Jahrtausend, Suhrkamp. Frankfurt am Main: Verlag.

Lipiěnik, B., Možina S. (1993). Psihologija v podjetjih. Ljubljana: DZS.

Marentič-Požarnik, B. (2000). Psihologija učenja in pouka. Ljubljana: DZS.

Mesner-Andolšek, D. (1995). Organizacijska kultura. Ljubljana: Gospodarski vestnik.

Quinn, J. B. (1996). Making the most from the best. Harward Business Review, March-April.

Thomson, R. (1998). People management, London: Orion Business Book.

Treven, S. (1998), Management človeških virov. Ljubljana: Gospodarski vestnik. 